$\xi=$

\title{
Evaluation of major nutritional components and phytochemical screening of four different Bangladeshi branded unifloral honey and their brine shrimp toxicity study
}

\author{
Md. Mahmodul Hasan ${ }^{1}$, Md. Jahirul Islam ${ }^{1}$, Subodh Kumar Sarkar ${ }^{2}$, Nurul Absar ${ }^{1}$ \\ ${ }^{1}$ Department of Biochemistry and Biotechnology, University of Science and Technology Chittagong (USTC), \\ Foy's Lake, Khulshi-4202, Chittagong, Bangladesh \\ ${ }^{2}$ Department of Biochemistry, Primeasia University, Dhaka-1213, Bangladesh \\ *Corresponding author E-mail: sksarkar11bio@yahoo.com
}

\begin{abstract}
The research work was conducted to investigate the biochemical composition of four different Bangladeshi branded unifloral honey. The honey from Litchi (Litchi chinensis), Black cumin (Nigella sativa), Coriander (Coriandrum sativum), Mustard (Brassica campestris) were used. We investigated color, $\mathrm{pH}$, Moisture, Dry matter ,Specific gravity, Total sugar, Reducing sugar, Non reducing sugar, Crude protein, Water soluble protein, Lipid, Ash, Total Carbohydrate, Metabolizable energy, Vitamin C and minerals content. The result revealed the presence of nutrient constituent among the varieties comprising $\mathrm{pH}(3.47$ to 4.06$)$,specific gravity(1.32 to 1.37$)$, dry matter(85.2 to $86.6 \%)$, moisture( 13.4 to $14.7 \%)$, ash $(0.64$ to $0.66 \%)$,lipid( 0.14 to $0.16 \%)$,crude protein( 0.63 to $0.73 \%)$, total carbohydrate( 83.70 to $85.18 \%)$, metabolizing energy(2763.59 to $2808.95 \mathrm{Kcal} / \mathrm{Kg}$ ), total sugar(77.36 to $81.2 \%$ ), reducing sugar(60.5 to $63.03 \%)$,non-reducing sugar(16.61 to $18.17 \%$ ), vitamin C (4.63 to $6.36 \mathrm{mg} \%$ ), and minerals such as Calcium(6.36 to $7.87 \mathrm{mg} \%$ ) and Iron(1.62 to $1.89 \mathrm{mg} \%)$ respectively. Moreover, alkaloids, flavonoids found in all varieties but only polyphenols was absent in Black cumin varieties. In the cytotoxic activity studies, LC50 values were obtained in the range of 4800 to $4966.7 \mu \mathrm{g} / \mathrm{ml}$.
\end{abstract}

Keywords: Unifloral Honey; Biochemical Analysis; Sugar; Cytotoxic Effect.

\section{Introduction}

Honey is the most familiar and widely distributed delicious food of Bangladesh. It is a source of nutrients in human diet, which are essential for maintaining proper health. Honey mainly consists of sugars and water. Apart from sugars, honey also contains several vitamins especially $\mathrm{B}$ complex and vitamin $\mathrm{C}$, together with a lot of minerals such as calcium, copper, iron, magnesium, manganese, phosphorus, potassium and zinc are also present (M Asaduzzam et.al.,2015). Honey contains at least 181 constituents (Bogdanov et.al, 2008, Gheldof et.al, 2002). The other constituents of honey are amino acids, antibiotic-rich inhibine, proteins and phenol antioxidants (Wang J et.al. 2011). It also contains other bioactive substances such as phenolic constituents, flavonoids, organic acids, carotenoid-derived compounds, nitric oxide (NO), metabolites, amino acids and protein (Arriage et.al, 2011, Bereta et.al, 2010). The presence of enzymes such as glucose oxidase has also been documented in honey (Jaganathan et.al, 2009). Furthermore, high levels of ascorbic acid, catalase, peroxidase, flavonoids, phenolic acids, and carotenoids ensure a high level of antioxidants in honey (Bosi G et.al., 1978). Although the honey therapeutic action has been taken some attention by researchers, studies only have been done on screening the raw honey samples on antimicrobial activity (Taormina et al., 2001, Al-Mamary et al., 2002 ; Kucuk et al., 2007; Basualdo et al., 2007 ; Estevinho et al., 2008; Truchado et al., 2009; Alvarez-Suarez et al. 2010; Silici et al, 2010) and on antioxidant capacity (Rauha et al., 2000; Frankel et al., 1998; Estevinho et al., 2008; Alvarez-Suarez et al., 2010;Gomes et al.,2010., Silici et al, 2010). To our knowledge, there are limited studies on the antibiofilm (Badet and Quero et.al, 2011) and cytotoxic activity (Jaganathan et al., 2010; Ceylan, 2013) of the honeys. The objective of the current studies was to investigate the biochemical and cytotoxic activity of four different Bangladeshi branded unifloral honeys.

\section{Materials and methods}

\subsection{Sample collection}

Four unifloral honeys such as Litchi (Litchi chinensis), Black cumin (Nigella sativa), Coriander (Coriandrum sativum), Mustard (Brassica campestris) were collected from BCSIR Laboratory, Rajshahi, Bangladesh.

\subsection{Proximate chemical analysis of unifloral honey}

\subsubsection{Determination of color}

The intensity of color of different varieties of honey was measured by spectrophotometrically and presented as the net absorbance at A (560-720 nm), according to the method of (Huidobro and Simal., 1984). 


\subsubsection{Determination of $\mathbf{p H}$}

$\mathrm{pH}$ of the different unifloral honey were determined using electrode assembly $\mathrm{pH}$ meter. Standard buffer solution of $\mathrm{pH} 7.0$ or 4.0 was used for this purpose.

\subsubsection{Determination of specific gravity}

The specific gravity of honey was determined by the method of (Kalimuddin, 1976).

\subsubsection{Determination of moisture contents of honey}

Moisture content was determined by standard official method of analysis of AOAC Eighteenth edition (2005) revision (2010).

\subsubsection{Determination of ash content of honey}

Ash content was determined by the standard method of AOAC (2005).

\subsubsection{Determination of dry matter content of honey}

Dry matter content was calculated by from the data obtained for percentage of moisture content.

\subsubsection{Determination of total protein content of honey}

Protein content of the different varities of unifloral honey was determined by the method of Micro-Kjeldahl of AOAC (2005).

\subsubsection{Determination of water soluble protein}

Water soluble protein content of honey was determined by the following method of (Lowry et.al., 1951) using BSA as the standard.

\subsubsection{Determination of lipid content of honey}

Lipid content of the different varieties of honey was determined by the method of (Bligh and Dyer., 1959).

\subsubsection{Determination of total sugar content of honey}

Total sugar content was determined calorimetrically by the anthrone method as described in Laboratory Manual in Biochemistry (Jayarman et.al., 1981).

\subsection{Determination of reducing sugar content of honey}

Reducing sugar content of the honey was determined by Dinitrosalicylic acid method (Miller et.al., 1972).

\subsubsection{Determination of non-reducing sugar content of honey}

Non-reducing sugar content of the honey was calculated from the following formula as reported by (Ranganna, S... 1979).

$\%$ of non-reducing sugar $=(\%$ of total sugar $-\%$ of reducing sugar).

\subsubsection{Determination of carbohydrate content}

Carbohydrate contents of the honey sample were determined by calculation (by difference) as follows:

$\%$ Carbohydrate $=100 \%-(\%$ Moisture $+\%$ Crude Fat $+\%$ Crude Protein $+\%$ Ash) .

\subsubsection{Determination of metabolizable Energy (ME)}

ME was calculated separately for four different unifloral honey samples. Calculation was performed by mathematical formula as per (Ludhi et al., 1976).

ME $(\mathrm{Kal} / \mathrm{kg})=32.95(\%$ Crude protein $+\%$ Crude Fat $\mathrm{x} 2.25+\%$ Carbohydrate)-29. 20.

\subsubsection{Vitamin}

For standard sample: Take 0 to $1.0 \mathrm{ml}$ of the standard vitamin solution in different test tubes and make volume to $1.0 \mathrm{ml}$ with chloroform. Add $2.0 \mathrm{ml}$ of TCA solution in chloroform to each tube and read the absorbency at $620 \mathrm{~nm}$ against blank which contains only solvent.

For honey sample: Add $2.0 \mathrm{ml}$ of $95 \%$ ethanol and $4.0 \mathrm{ml}$ of petroleum ether to the supplied sample. Shake for 3 minutes and take off all petroleum ether layer evaporate to dryness under $\mathrm{N}_{2}$ gas or by fan. Dissolve in $1.0 \mathrm{ml}$ chloroform. Then add $2.0 \mathrm{ml}$ of TCA solution and take reading immediately.

Determination of Vitamin-C content of honey:

Vitamin-C content of honey was determined by the titrimetric method (Bessey and King, 1933).

\subsubsection{Determination of mineral content of honey}

Calcium: Calcium content of the honey was determined by the method as described in Practical Physiological chemistry (Vogel et.al., 1978).

Iron: Iron content of the honey was determined spectrophotometrically by Thiocyanate method as described in Practical Physiological chemistry (Vogel et.al., 1978).

\subsubsection{Statistical analysis}

All analytical determinations and measurements were performed in triplicates. Values of different parameters are expressed as the mean \pm standard deviation. Statistical analysis of all the assay results was done using the Microsoft Excel program (2007).

\subsubsection{Phytochemical activity of honey}

The qualitative screening test for phytochemicals such as alkaloids, flavonoids and polyphenols of unifloral honey samples were carried out by Official Methods of Analysis (Edeoga et.al. 2005).

\subsubsection{Brine shrimp lethality bio-assay (cytotoxic study)}

The cytotoxicity of the extracts was tested on brine shrimp nauplii (Artemia salina Leach) according brine shrimp lethality bioassay (Meyer BN et.al., 1982). For hatching eggs were kept in brine with a constant oxygen supply for 48 hours. The matured nauplii were then used in the experiment. Test sample was applied at different concentrations and the number of viable organisms was applied was counted after 24 hours for determination of $\mathrm{LC}_{50} \mathrm{val}-$ ues. DMSO was used as a solvent and also as negative control test was one in triplicate.

\section{Results and discussion}

The study was under taken to evaluate the chemical composition, phytochemical analysis and cytotoxic analysis of some Bangladeshi unifloral honey, which are important to the quality of the product.

The net absorbance of four brands of honey shown in Table- 1 . Among four honeys analyzed the color ranged 0.29 to $0.65 \mathrm{au}$ (absorbance unit). Black cumin honey showed the highest net absorbance i.e. 0.65au, while Coriander honey showed the lowest such as $0.29 \mathrm{au}$. The revealed results are closely related as reported by (Alvarez et al., 2011). The value of $\mathrm{pH}$, Specific gravity, moisture, dry matter, and ash of four different unifloral honeys are shown in Table-2. The $\mathrm{pH}$ of brands of honey was studied within acidic range. The range of the $\mathrm{pH}$ of four brands of unifloral honey was from $3.47 \pm 0.2$ to $4.06 \pm 0.15$. The respective value that are comparatively found similar with the findings of (Farida Iftikhar et.al, 2014) and (Khalil et.al. 2001). The range of specific gravity of the unifloral honey was $1.32 \pm 0.007$ to $1.37 \pm 0.005$. The highest amount of specific gravity found in Mustard honey i.e. 1.37 \pm 0.005 and lowest in Coriander honey $1.32 \pm 0.007$, the others honey specific gravity such as Black cumin, Litchi honey were $1.36 \pm 0.01$ 
and $1.36 \pm 0.03$ respectively, which are very similar to the findings of (Khalil et.al, 2001).

The dry matter content was found to be varied between $85.2 \pm 0.23$ to $86.6 \pm 0.1 \%$, the revealed results are closely related as reported by (Khalil et.al, 2001). The moisture and ash content of four unifloral honey to be compared to the reported data by (Farida Iftikhar et.al, 2014, Khalil et.al, 2001, Matiar Rahmam et .al, 2015).

The lipid, total protein, Water soluble protein, Total Carbohydrate and Metabolizable energy contents of honey are shown in Table-3. Lipid content in different varieties range from $0.14 \pm 0.003$ to $0.16 \pm 0.007 \%$. The highest value of lipid content was found in Mustard honey $(0.16 \pm 0.007 \%)$, whereas lowest in Litchi and Coriander honey $(0.14 \pm 0.003 \%)$. The results of present study are in agreement with earlier results as reported by (Khalil et.al, 2001, Matiar Rahmam et .al, 2015).

Total protein content of different unifloral honey ranged from $0.63 \pm 0.01-0.73 \pm 0.009 \%$. The highest value of protein found in Mustard honey $(0.73 \pm 0.009 \%)$ and lowest in Litchi honey $(0.63 \pm 0.01 \%)$. The results obtained in this studies are in line with earlier studies reported by (Khalil et.al, 2001, Matiar Rahmam et .al, 2015).

The water soluble protein content of different varieties of honey ranged from $0.41 \pm 0.01-0.53 \pm 0.01 \%$. As compared with the reference value of (Khalil et.al, 2001), results were almost found approximately.

Total carbohydrate values in different unifloral honey varieties ranged from 83.70 to $85.18 \%$. The highest value of total carbohydrate was found in Litchi $(85.18 \pm 0.03)$ and lowest in Black cumin $(83.70 \pm 0.06)$. These findings are confirmed with the earlier results reported by (Matiar Rahmam et.al, 2015).

Metabolizing energy (ME) content in different honey varieties ranged from 27.63 .59 to $2808.95 \mathrm{Kcal} / \mathrm{Kg}$. The highest metabolizable energy found in Litchi $(2808.95 \mathrm{Kcal} / \mathrm{Kg})$ and lowest in Black cumin $(2763.59 \mathrm{Kcal} / \mathrm{Kg})$ varieties. The results obtained in this study are in line with earlier reported by (Matiar Rahmam et.al.2015). The honey proteins are mainly in the form of enzymes. Glucose oxidase and Catalase regulate the production of $\mathrm{H}_{2} \mathrm{O}_{2}$; which serve as one of the anti-bacterial factor in honey (Oddo LP et.al., 1999).

The Vitamin-C, Total sugar, reducing sugar and non-reducing sugar content of different varieties of honey are shown in Table-4. The range of total sugar, reducing sugar and non-reducing sugar content of four brands of honey was $77.36 \pm 0.15$ to $81.2 \pm 0.3 \%$, $60.5 \pm 0.2$ to $63.03 \pm 0.03 \%$ and $16.61 \pm 0.2$ to $18.17 \pm 0.2 \%$ respec- tively. So, our present data is closely related to the (Nayik et al., 2016, Farida Iftikhar et.al, 2014, Khalil et.al.,2001, Matiar Rahmam et .al.,2015) reported data. The data indicated that honey contained a very large amount of sugar. So it can be considered as a good source of sugar. The vitamin- $\mathrm{C}$ content was found to be varied between $4.63 \pm 0.15$ to $6.36 \pm 0.015$ (mg/100gm).

The highest vitamin $\mathrm{C}$ content was found in Litchi honey $(6.36 \pm 0.015 \mathrm{mg} / 100 \mathrm{gm})$ and lowest in Coriander honey $(4.63 \pm 0.15 \mathrm{mg} / 100 \mathrm{gm})$. These results are agreeable with the findings of (Khalil et.al, 2001).

The mineral contents of honey showed in Table-5. The amount of calcium (Ca) contents of Litchi, Black cumin, Mustard, Coriander honey were $(7.4 \pm 0.1,7.87 \pm 0.03,6.59 \pm 0.03,6.36 \pm 0.1) \mathrm{mg} / 100 \mathrm{~g}$. The amount of Iron $(\mathrm{Fe})$ contents Litchi, Black cumin, Mustard, Coriander honey were $(1.89 \pm 0.09,1.83 \pm 0.02,1.66 \pm 0.03$, $1.62 \pm 0.01) \mathrm{mg} / 100 \mathrm{~g}$. So, our present data is closely related to the (Khalil et.al. 2001) reported data. Magnesium, Calcium, Iron and Potassium in the human required for building red blood cell and for body mechanism (FAO, 1996).

The results of phytochemical screening of four different unifloral honeys are presented in Table- 6 . It is cleared from the data that high amount of alkaloids present in Mustard honey and there is no polyphenols present in Black cumin honey. It has been found that alkaloids, flavonoids and polyphenols are slightly present in Coriander honey. Moreover, flavonoids are moderately found in Black cumin honey. Polyphenols in honey are responsible for its biological functions such as antioxidant activity (Gheldof et al.,2002) Flavonoids inhibits bacterial strains; viral enzymes, i.e reverse transcriptase and protease, and destroy some pathogenic protozoans (Havsteen.,2002).

Table-7 shows the results of the brine shrimp lethality bioassay after $24 \mathrm{~h}$ of exposure to the aqueous extract of four varieties of unifloral honey. The $\mathrm{LC}_{50}$ value (Concentration at which $50 \%$ mortality of the brine shrimp nauplli occur) was determinded from the graph by extrapolation and the $\mathrm{LC}_{50}$ values of four varieties of unifloral honey, Litchi, Black cumin, Coriander and Mustard honey were found to be about $4966.7 \mu \mathrm{g} / \mathrm{ml}, 4958.3 \mu \mathrm{g} / \mathrm{ml}, 4800$ $\mu \mathrm{g} / \mathrm{ml}, 4858.3 \mu \mathrm{g} / \mathrm{ml}$, respectively. From the results of brine shrimp lethality bioassay, it is concluded that the aqueous extract of four varieties of unifloral honey are non-toxic on the brine shrimp as they gave $\mathrm{LC}_{50}$ values much greater than $100 \mu \mathrm{g} / \mathrm{ml}$ as it was also established that extracts of nine Turkish honey is considered to be non-toxic since it showed LC $_{50}$ values greater than 100 $\mu \mathrm{g} / \mathrm{ml}$ on the brine shrimps (Ceylan., 2013).

Table 1: Physical Characteristics of the honey

\begin{tabular}{llll}
\hline Test honey & A-660nm & A-530nm & Net absorbance \\
\hline Litchi & 0.45 & 0.78 & 0.33 \\
Black cumin & 0.85 & 1.5 & 0.65 \\
Mustard & 0.33 & 0.68 & 0.35 \\
Coriander & 0.43 & 0.72 & 0.29 \\
\hline
\end{tabular}

Table 2: The Value of Ph., Specific Gravity, Moisture, Dry Matter, and Ash content of different brands of unifloral honey

\begin{tabular}{llllll}
\hline Test honey & $\mathrm{pH}$ & Specific gravity & Moisture $(\%)$ & Dry matter $(\%)$ & Ash $(\%)$ \\
\hline Litchi & $3.47 \pm 0.2$ & $1.36 \pm 0.03$ & $13.4 \pm 0.1$ & $86.6 \pm 0.1$ & $0.64 \pm 0.01$ \\
Black cumin & $3.66 \pm 0.15$ & $1.36 \pm 0.01$ & $14.7 \pm 0.23$ & $85.2 \pm 0.23$ & $0.66 \pm 0.006$ \\
Mustard & $3.58 \pm 0.16$ & $1.37 \pm 0.005$ & $13.8 \pm 0.05$ & $86.2 \pm 0.05$ & $0.65 \pm 0.02$ \\
Coriander & $4.06 \pm 0.15$ & $1.32 \pm 0.007$ & $13.7 \pm 0.05$ & $86.3 \pm 0.05$ & $0.66 \pm 0.02$ \\
\hline
\end{tabular}

The values are mean \pm standard deviation mean $(\mathrm{n}=3)$.

Table 3: The Value of Lipid ,Protein, Water Soluble protein, Carbohydrate, Metabolizable Energy content of four different brands of unifloral honey

\begin{tabular}{llllll}
\hline Test honey & Lipid $(\mathrm{gm} / 100 \mathrm{gm})$ & Protein $(\mathrm{gm} / 100 \mathrm{gm})$ & $\begin{array}{l}\text { Water soluble protein } \\
(\mathrm{gm} / 100 \mathrm{gm})\end{array}$ & $\begin{array}{l}\text { Carbohydrate } \\
(\mathrm{gm} / 100 \mathrm{gm})\end{array}$ & $\begin{array}{l}\text { Metabolizable Ener- } \\
\mathrm{gy}(\mathrm{Kcal} / \mathrm{Kg})\end{array}$ \\
\hline Litchi & $0.14 \pm 0.003$ & $0.63 \pm 0.01$ & $0.41 \pm 0.01$ & $85.18 \pm 0.03$ & 2808.95 \\
Black cumin & $0.15 \pm 0.02$ & $0.71 \pm 0.01$ & $0.47 \pm 0.015$ & $83.70 \pm 0.06$ & 2763.59 \\
Mustard & $0.16 \pm 0.007$ & $0.73 \pm 0.009$ & $0.53 \pm 0.01$ & $84.60 \pm 0.02$ & 2794.92 \\
Coriander & $0.14 \pm 0.015$ & $0.65 \pm 0.02$ & $0.44 \pm 0.015$ & $84.84 \pm 0.02$ & 2798.43 \\
\hline
\end{tabular}

The values are mean \pm standard deviation mean $(n=3)$. 
Table 4: The value of Total sugar, Reducing sugar, Non-reducing sugar and Vitamin-C content of four different brands of unifloral honey

\begin{tabular}{lllll}
\hline Test honey & Total sugar $(\mathrm{gm} / 100 \mathrm{gm})$ & $\begin{array}{l}\text { Reducing sugar } \\
(\mathrm{gm} / 100 \mathrm{gm})\end{array}$ & $\begin{array}{l}\text { Non-reducing sugar } \\
(\mathrm{gm} / 100 \mathrm{gm})\end{array}$ & Vitamin-C (mg/100gm) \\
\hline Litchi & $81.2 \pm 0.3$ & $63.03 \pm 0.03$ & $18.17 \pm 0.2$ & $6.36 \pm 0.015$ \\
Black cumin & $78.71 \pm 0.1$ & $62.1 \pm 0.2$ & $16.61 \pm 0.2$ & $5.71 \pm 0.1$ \\
Mustard & $80.06 \pm 0.15$ & $62.58 \pm 0.07$ & $17.48 \pm 0.2$ & $5.42 \pm 0.08$ \\
Coriander & $77.36 \pm 0.15$ & $60.5 \pm 0.2$ & $16.86 \pm 0.15$ & $4.63 \pm 0.15$ \\
\hline
\end{tabular}

The values are mean \pm standard deviation mean $(n=3)$

Table 5: Mineral Contents of four different brands of unifloral honey

\begin{tabular}{lll}
\hline Test honey & $\mathrm{Ca}(\mathrm{mg} / 100 \mathrm{gm})$ & $\mathrm{Fe}(\mathrm{mg} / 100 \mathrm{gm})$ \\
\hline Litchi & $7.4 \pm 0.1$ & $1.89 \pm 0.09$ \\
Black cumin & $7.87 \pm 0.03$ & $1.83 \pm 0.02$ \\
Mustard & $6.59 \pm 0.03$ & $1.66 \pm 0.03$ \\
Coriander & $6.36 \pm 0.1$ & $1.62 \pm 0.01$ \\
\hline
\end{tabular}

The values are mean \pm standard deviation mean $(\mathrm{n}=3)$.

Table 6: Phytochemical Screening of four different brands of unifloral honey

\begin{tabular}{llll}
\hline Test honey & Alkaloids & Flavonoids & Polyphenols \\
\hline Litchi & + & ++ & ++ \\
Black cumin & ++ & ++ & - \\
Mustard & +++ & + & ++ \\
Coriander & + & + & + \\
\hline
\end{tabular}

+++, Highly present, ++, moderately present, +, slightly present, -, Nil.

Table 7: Cytotoxic Test for four different brands of unifloral honey

\begin{tabular}{|c|c|c|c|c|c|c|c|}
\hline Test sample & $\begin{array}{l}\text { Vol. of sample } \\
(\mu 1)\end{array}$ & $\begin{array}{l}\text { Conc.of sample } \\
(\mu \mathrm{g} / \mathrm{ml})\end{array}$ & $\begin{array}{l}\text { Log conc. } \\
(\log C)\end{array}$ & $\begin{array}{l}\text { No.of shrimp } \\
\text { taken in each } \\
\text { vial }\end{array}$ & No. of survival & $\%$ of mortality & $\begin{array}{l}\mathrm{LC}_{50} \\
(\mu \mathrm{g} / \mathrm{ml})\end{array}$ \\
\hline \multirow{6}{*}{ Litchi } & 10 & 1192 & 3.07 & 10 & 8 & 20 & \multirow{7}{*}{4966.7} \\
\hline & 20 & 2384 & 3.38 & 10 & 8 & 20 & \\
\hline & 30 & 3576 & 3.55 & 10 & 7 & 30 & \\
\hline & 40 & 4768 & 3.67 & 10 & 6 & 40 & \\
\hline & 50 & 5960 & 3.78 & 10 & 6 & 40 & \\
\hline & 100 & 11920 & 4.07 & 10 & 4 & 60 & \\
\hline \multirow{5}{*}{ Black cumin } & 20 & 2380 & 3.38 & 10 & 7 & 30 & \\
\hline & 30 & 3570 & 3.55 & 10 & 6 & 40 & \multirow{4}{*}{4958.3} \\
\hline & 40 & 4760 & 3.68 & 10 & 5 & 50 & \\
\hline & 50 & 5950 & 3.77 & 10 & 4 & 60 & \\
\hline & 100 & 11900 & 4.08 & 10 & 3 & 70 & \\
\hline \multirow{5}{*}{ Coriander } & 10 & 1152 & 3.06 & 10 & 9 & 10 & \multirow{7}{*}{4800} \\
\hline & 20 & 2304 & 3.36 & 10 & 8 & 20 & \\
\hline & 30 & 3456 & 3.54 & 10 & 8 & 20 & \\
\hline & 50 & 5760 & 3.76 & 10 & 7 & 30 & \\
\hline & 100 & 11520 & 4.06 & 10 & 5 & 50 & \\
\hline \multirow{6}{*}{ Mustard } & 10 & 1166 & 3.07 & 10 & 7 & 30 & \\
\hline & 20 & 2332 & 3.37 & 10 & 7 & 30 & \\
\hline & 30 & 3498 & 3.54 & 10 & 6 & 40 & \multirow{4}{*}{4858.3} \\
\hline & 40 & 4664 & 3.67 & 10 & 4 & 60 & \\
\hline & 50 & 5830 & 3.77 & 10 & 4 & 60 & \\
\hline & 100 & 11660 & 4.07 & 10 & 3 & 70 & \\
\hline
\end{tabular}

\section{Conclusion}

In conclusion, the nutritional studies suggest that Litchi and Black cumin honey contains a good amount of nutritional components. These varieties also have good biological effects like cytotoxic activity. Further study is necessary to elucidate the mechanisms behind the traditional effects.

\section{References}

[1] Arriaga E, Navarro-Calvo AL, Díaz-Carbajal E, (2011). Botanical characterisation of Mexican honeys from a subtropical region (Oaxaca) based on pollen analysis. Grana; 50: 40-45. http://dx.doi.org/10.1080/00173134.2010.537767.

[2] Al-Mamary, M., Al-Meeri, A., \& Al-Habori, M. (2002). Antioxidant activities and total phenolics of different types of honey. Nutrition Research, 22, 1041-1047. http://dx.doi.org/10.1016/S02715317(02)00406-2.

[3] Alvarez-Suarez, J.M., Tulipani, S., Romandini, S., Bertoli, E., Battino, M., (2010). Contribution of honey in nutrition and human health: a review. Mediterranean Journal of Nutrition and Metabo- lism 3, 15-23. http://link.springer.com/article/10.1007/s12349-0090051-6. http://dx.doi.org/10.1007/s12349-009-0051-6.

[4] AOAC. (2005). Official Method of Analysis. Ash Analysis 923.03 The Official Methods of Analysis of AOAC International. 18th Ed. Current through revision, (2010).

[5] AOAC. (2005). Official Method of Analysis. Protein Analysis 984.13. The Official Methods of Analysis of AOAC International. 18th Ed. Current through revision, (2010).

[6] Alvarez,Liset Maldonado.,(2011).Honey proteins and their interaction with polyphenols. MS thesis. Brock University, page-49. http://biblioteca.versila.com/10246061.

[7] Bogdanov S, Jurendic T, Sieber R, Gallmann P.,(2008) Honey for nutrition and health: a review. $J$ Am CollNutr; 27: 677689.http://dx.doi.org/10.1080/07315724.2008.10719745.

[8] Beretta G, Gelmini F, Lodi V, Piazzalunga A, MaffeiFacino R., (2010) Profile of nitric oxide (NO) metabolites (nitrate, nitrite and $\mathrm{N}$-nitroso groups) in honeys of different botanical origin: nitrate accumulation as index of origin, quality and of therapeutic opportunities. J Pharm Biomed Anal; 53: 343-349. http://dx.doi.org/10.1016/j.jpba.2010.04.010.

[9] Bosi G, Battalglini M., (1978). Gas chromatographic analysis of free and protein amino acids in some unifloral honeys. Journal of 
$\begin{array}{lcr}\text { Apicultural } & \text { Research; } & 17: \\ \text { https://doi.org/10.1080/00218839.1978.11099920. }\end{array}$

10] Basualdo, C., Sgroy, V., Finola, M.S., Marioli, J.M., (2007). Comparison of the antibacterial activity of honey from different provenance against bacteria usually isolated from skin wounds. Veterinary Microbiology 124, 375-381. https://doi.org/10.1016/j.vetmic.2007.04.039.

[11] Badet, C. and Quero, F. (2011).The in vitro effect of manuka honeys ongrowth and adherence of oral bacteria. Anaerobe, 17, 19-22. http://dx.doi.org/10.1016/j.anaerobe.2010.12.007.

[12] Bessey, O.A. and C.G.King., 1933.The distribution of vitamin-C in plant and animal tissue and its determination, J.Biol.Chem, 103:687.

[13] Bligh EG and Dyer W (1959) Total Lipid Extraction and Purification. Can. J.Biochem. Physiol. 37: 911 http://dx.doi.org/10.1139/o59-099.

[14] Ceylan, O., Uganda, A., Isılogl, M. and Ozcan, F. (2013). Evaluation of the Antibacterial, Antibiofilm, Antioxidant, And Cytotoxic Effects Of Some Turkish Honeys, Apimondia to, XXXXIII International Apicultural Congress, 29 september-04 Octab of 2013, Kyiv, Ukraine.

[15] Estevinho, L., Prereira, A.P., Moreira, L., Dias, L.G., Pereira, E., (2008). Antioxidant and antimicrobial effects of phenolic compounds extracts of Northeast Portugal honey. Food and Chemical Toxicology

46 , http://dx.doi.org/10.1016/j.fct.2008.09.062.

[16] Edeoga, H.O., D.E. Okwu and B.O. Mbaebie, (2005). Phytochemical constituents of some Nigeria medicinal plants. Afr. J. Biotechnol., 4(7): 685-688. http://dx.doi.org/10.5897/AJB2005.000-3127.

[17] Farida Iftikhar,Rashid Mahmood, Noor Islam, Ghulam Sarwar,M.Ashif Masood, Hammad Shafiq.,(2014). Physicochemical analysis of honey samples collected from local markets of Rawalpindi and Islamabad,Pakistan. American journal of Biochemistry, 4(2):35-40.

[18] FAO/WHO/IAEA, (1996). Trace Elements in Human Nutrition and Health, WHO,Geneva.

[19] Frankel, S., Robinson, G.E., Berenbaum, M.R., (1998). Antioxidant capacity and correlation characteristics of 14 unifloral honeys. Journal of Apiculture Research 37, 27-31. http://dx.doi.org/10.1080/00218839.1998.11100951.

[20] Gheldof N, Wang XH, Engeseth NJ. (2002). Identification and quantification of antioxidant components of honeys from various floral sources. $J$ Agric Food Chem; 50: 5870-5877. http://www.ncbi.nlm.nih.gov/pubmed/12358452. http://dx.doi.org/10.1021/jf0256135.

[21] Gomes, S., Dias, L.G., Moreira, L.L., Rodrigues, P., Estevinho, L., (2010). Physicochemical, microbiological and antimicrobial properties of commercial honeys from Portugal. Food and Chemical Toxicology 48, 544-548. http://dx.doi.org/10.1016/j.fct.2009.11.029.

[22] G.L.Miller, (1959); Use of dinitrosalicylic acid reagent for determination of reducing sugar. Anal. Chem. 31(3):426-428. http://dx.doi.org/10.1021/ac60147a030.

[23] Havsteen BH (2002) Biochemistry and Medical Significance of the flavonoids, Pharmacol Ther. 96(2-3):67 - 202. http://dx.doi.org/10.1016/S0163-7258(02)00298-X.

[24] Huidobro J. F and Simal J., (1984). Determinacion del color y de la tubidez en la mieles. Anal. Bromatol. 36(2), 225-245.

[25] Jaganathan SK, Mandal M., (2009) Antiproliferative effects of honey and of its polyphenols: A review.J Biomed Biotechnol; article ID 830616. http://dx.doi.org/10.1155/2009/830616.

[26] J.Jayarman, (1981); Laboratory manual in Biochemistry, 1st Ed., Wiley Eastern Ltd.New Delhi, 75.

[27] Jaganathan, S. K, Mandal, S. M., Jana, S. K., Das, S.; Mandal, M. (2010). Studies on the phenolic profiling, anti-oxidant and cytotoxic activity of Indian honey: in vitro evaluation. Natural Products Research $24 \quad$ (14):1295-306. http://dx.doi.org/10.1080/14786410903184408.

[28] Kucuk, M., Kolaylı, S., Karaoglu, S., Ulusoy, E., Baltacı, C., Candan, F., (2007). Biological activities and chemical composition of three honeys of different types from Anatolia. Food Chemistry 100, 526-534. http://dx.doi.org/10.1016/j.foodchem.2005.10.010.

[29] Kalimuddin, M., A., (1976). Text Book of Practical Physics (4 ${ }^{\text {th }}$ Ed.) Bangladesh, 84.

[30] Lowry, O.H., Rosebrough N.J, Farr A.L and Randall R.L, (1951).Protein measurement with the folin phenol reagent. J.Biol.Chem, 183:265-275.

[31] Lodhi GN, Daulat Singh and Ichhponani JS (1976). Variation in nutrient content of feeding stuffs rich in protein and reassessment of the chemical method for metabolizable energy estimation for poul- try. Journal of Agricultural Science, 86(2): 293-303 http://dx.doi.org/10.1017/S0021859600054757.

[32] M Asaduzzaman, M Sohanur Rahman, Sirajam Munira, M Muedur Rahman, Minarul Islam, Mhadi Hasan, M Abdul Hai Siddique, (2015); Analysis of biochemical composition of honey and its antioxidant, phytochemical and anti-bacterial properties. J.Biomedical and Pharmaceutical Research 4(4), 69-81.

[33] Meyer BN, Ferringni NR, Puam JE, Lacobsen LB, Nicols DE, McLaughilin JL. (1982). Brine Shrimp: A convenient general bioassay for active constituents. Planta Med. 45: 31-32. http://dx.doi.org/10.1055/s-2007-971236.

[34] M.Ibrahim Khalil, Md.Abdul Motalib, A.S.M.Anisuzzaman,Zakia Sultana Sathi, M.A.Hye and M.Shahjahan.,(2001).Biochemical analysis of different brands of unifloral honey available at the north region of Bangladesh. Asian network for scientific Information, vol.1 (6):385-388. http://dx.doi.org/10.3923/jms.2001.385.388.

[35] M Asaduzzaman,M shohanur Rahman, Sirjam Munira, M Muedur Rahman.,(2015).Analysis of biochemical composition of honey and its anti-oxidant, Phytochemical and anti-bacterial properties. J Biomedical and pharmaceutical Research, 4(4), 69-81.

[36] Mbwambo,Z.H., M.J.Moshi, P.J.Masimba, M.C.Kapingu, R.S. O.Nondo., (2007). Antimicrobial activity and brine shrimp toxicity of extracts of Terminalia brownii roots and stem. BMC complem.AlternativeMed.,Vol.7,10.1186/1472-6882-7-9. http://dx.doi.org/10.1186/1472-6882-7-9.

[37] Nayik.G.A.,B.N.Dar, V.Nanda.,(2016). Physico-chemical, rheological and sugar profile of different unifloral honeys from Kashmir valley of India. Arabian Journal of Chemistry. http://dx.doi.org/10.1016/j.arabjc.2015.08.017.

[38] Oddo LP, Piazza MG, Pulcini P. (1999).Invertase activity in Honey. Apidologie; 30: 57- 65. http://dx.doi.org/10.1051/apido:19990107.

[39] Rauha, J.P., Remes, S., Heinonen, M., Hopia, A., Kahkonen, M. Kujala, T., Pihlaja, K., Vuorela, H., Vuorela, P., (2000). Antimicrobial effects of Finnish plant extracts containing flavonoids and other phenolic compounds. International Journal of Food Microbiology 56, 3-12. http://dx.doi.org/10.1016/S0168-1605(00)00218-X.

[40] Ranganna,S. (1979). Manual of analysis of fruits and vegetables products. Tata McGraw-Hill Publishing Company Ltd. New Delhi, India, $312 \mathrm{pp}$.

[41] Silici, S., Sagdic, O., Ekici, L. (2010). Total phenolic content, antiradical, antioxidant and antimicrobial activities of Rhododendron honeys, Food Chemistry, 12, 238-243. http://dx.doi.org/10.1016/j.foodchem.2009.11.078.

[42] Taormina, P.J., Niemira, B.A., Beuchat, L.R., (2001). Inhibitory activity of honey against foodborne pathogens as influenced by the presence of hydrogen peroxide and level of antioxidant power. International Journal of Food Microbiology; 69, 217-225. http://dx.doi.org/10.1016/S0168-1605(01)00505-0.

[43] Truchado, P., Ferreres, F., \& Tomas-Barberan, F. A. (2009). Liquid chromatography-tandem mass spectrometry reveals the widespread occurrence of flavonoid glycosides in honey, and their potential as floral origin markers. Journal of Chromatography, A, 1216, 72417248. http://dx.doi.org/10.1016/j.chroma.2009.07.057.

[44] Vogel,A.I., (1978).Vogel's Text book of Quantitative inorganic Analysis (4th Ed.) Longman Group Limited, England, pp: 741, 787, 808.

[45] Wang J, Li QX., (2011) .Chemical composition, character-ization, and differentiation of honey botanical and geographical origins. Adv Food Nutr Res; 62: 89-137. http://dx.doi.org/10.1016/B978-012-385989-1.00003-X. 